Boise State University

ScholarWorks

Biology Faculty Publications and Presentations

Department of Biological Sciences

$11-1-2017$

\title{
Fatal Attraction?: Intraguild Facilitation and Suppression Among Predators
}

Kelly J. Sivy

University of Alaska

Casey B. Pozzanghera

Boise State University

James B. Grace

US Geological Survey

Laura R. Prugh

University of Washington 


\title{
Fatal Attraction? Intraguild Facilitation and Suppression among Predators
}

\author{
Kelly J. Sivy, ${ }^{1, \star}$ Casey B. Pozzanghera, ${ }^{2}$ James B. Grace, ${ }^{3}$ and Laura R. Prugh ${ }^{4}$
}

1. Department of Biology and Wildlife, University of Alaska, Fairbanks, Alaska 99775; 2. Department of Biological Sciences, Boise State University, Boise, Idaho 83725; 3. US Geological Survey, Wetland and Aquatic Research Center, Lafayette, Louisiana 70506; 4. School of Environmental and Forest Sciences, University of Washington, Seattle, Washington 98195

Submitted March 31, 2017; Accepted June 9, 2017; Electronically published September 13, 2017

Online enhancements: appendix. Dryad data: http://dx.doi.org/10.5061/dryad.tj590.

\begin{abstract}
Competition and suppression are recognized as dominant forces that structure predator communities. Facilitation via carrion provisioning, however, is a ubiquitous interaction among predators that could offset the strength of suppression. Understanding the relative importance of these positive and negative interactions is necessary to anticipate community-wide responses to apex predator declines and recoveries worldwide. Using state-sponsored wolf (Canis lupus) control in Alaska as a quasi experiment, we conducted snow track surveys of apex, meso-, and small predators to test for evidence of carnivore cascades (e.g., mesopredator release). We analyzed survey data using an integrative occupancy and structural equation modeling framework to quantify the strengths of hypothesized interaction pathways, and we evaluated fine-scale spatiotemporal responses of nonapex predators to wolf activity clusters identified from radio-collar data. Contrary to the carnivore cascade hypothesis, both meso- and small predator occupancy patterns indicated guild-wide, negative responses of nonapex predators to wolf abundance variations at the landscape scale. At the local scale, however, we observed a near guild-wide, positive response of nonapex predators to localized wolf activity. Local-scale association with apex predators due to scavenging could lead to landscape patterns of mesopredator suppression, suggesting a key link between occupancy patterns and the structure of predator communities at different spatial scales.
\end{abstract}

Keywords: Canis lupus, Canis latrans, apex predators, facilitation, mesopredator release, suppression.

\section{Introduction}

Apex predators strongly influence community structure and food webs through pathways that affect the behavior and distribution of numerous species, including other predators (Ripple et al. 2014). Our current understanding of predator community dynamics is that they are largely based on negative

\footnotetext{
* Corresponding author. Present address: 3820 Ullrbahn Road, Fairbanks, Alaska 99709; e-mail: kjsivy@alaska.edu.

ORCIDs: Sivy, http://orcid.org/0000-0002-3598-3014; Grace, http://orcid.org /0000-0001-6374-4726; Prugh, http://orcid.org/0000-0001-9045-3107.

Am. Nat. 2017. Vol. 190, pp. 663-679. (C) 2017 by The University of Chicago. 0003-0147/2017/19005-57641\$15.00. All rights reserved. DOI: $10.1086 / 693996$
}

interactions such as intraguild competition and predation (Holt and Polis 1997; Palomares and Caro 1999; Linnell and Strand 2000). These top-down influences may result in substantial direct (e.g., mortality) and indirect (e.g., avoidance behaviors, elevated stress responses) effects that ultimately suppress the habitat use, distribution, and abundance of mesopredators (Ritchie and Johnson 2009). Given the rising efforts to restore apex predators in parts of North America and Europe (Chapron et al. 2014; Ripple et al. 2014), understanding how species interactions cascade throughout predator guilds is important for predicting community-wide responses to variations in apex predator presence.

Suppressive interactions among predators are pervasive in both terrestrial and aquatic systems worldwide (Prugh et. al 2009; Ritchie and Johnson 2009). Predator cascades, whereby apex predators suppress large-bodied mesopredators, which in turn suppress smaller predators and prey, may be common (Ripple et al. 2011, 2013). In North America, gray wolves (Canis lupus) may indirectly benefit red foxes (Vulpes vulpes) through suppression of coyotes (Canis latrans; Levi and Wilmers 2012; Newsome and Ripple 2015). In east Africa, African lions (Panthera leo) may indirectly benefit African wild dogs (Lycaon pictus) through hyena (Crocuta crocuta) suppression (Creel and Creel 1996). In Europe, red foxes respond to wolf and Eurasian lynx (Lynx lynx) abundance, with cascading effects on mountain hares (Lepus timidus; Elmhagen et. al 2010). And in Australia, suppression of red foxes and feral cats (Felis catus) by dingoes (Canis lupus dingo) may indirectly benefit small mammalian prey (Letnic et al. 2012).

Despite the prevalence of suppression-based cascades, positive interactions (e.g., facilitation) can exert similarly strong influences on community structure (Stachowicz 2001; Bruno et. al 2003). Scavenging is a ubiquitous yet arguably underappreciated interaction among predatory mammals, invertebrates, birds, and fish through which apex predators positively influence nonapex predators (Wilson and Wolkovich 2011). Carrion provisioning by apex predators provides a continuous influx of relatively low-cost food resources, which can 
facilitate the persistence of nonapex predators and stabilize communities when small prey is otherwise scarce (Ostfeld and Keesing 2000; Wilmers et al. 2003a; Pereira et al. 2014). This facilitative pathway could offset negative interactions and explain the lack of evidence for mesopredator suppression in some cases (Mitchell and Banks 2005; Gehrt and Prange 2007; Berger et al. 2008; Allen et al. 2014, 2015; Colman et al. 2014). Carrion is also a powerful local attractant. Although mesopredators may adjust home ranges to avoid encounters with territorial apex predators (Fuller and Keith 1981; Paquet 1991; Palomares et al. 1996; Arjo and Pletscher 1999), high degrees of spatial overlap are also documented (Berger and Gese 2007; van Dijk et al. 2008a). The degree of carrion provisioning by apex predators could therefore have a profound influence on spatial associations among predators.

Positive and negative interactions among predators have not typically been examined in an integrative framework, and our mechanistic understanding of how these interactions ripple throughout predator communities thus remains poor. Studies have mostly focused on pairwise or trispecies interactions, yet top-down effects may be diffuse in diverse predator guilds (Roemer et al. 2009). Continued study and emphasis on suppression cascades, while understandable, deflects attention away from the role of positive interactions and the conditions under which either suppression or facilitation prevails.

Mammalian carnivores present a diverse and globally distributed study guild to evaluate hypotheses that advance our understanding of positive and negative interaction pathways. Yet conducting a guild-wide assessment of carnivore interactions is logistically demanding, because carnivores are elusive and costly to capture, often persist at low densities, and can occupy home ranges larger than $1,000 \mathrm{~km}^{2}$ (e.g., wolves; Mech et al. 1998). Intact carnivore communities are relatively uncommon, and therefore, replication and randomization of treatments (e.g., predator removal) at scales necessary to yield strong inference is often impractical and can introduce numerous confounding factors (Ford and Goheen 2015). An alternative to replicated experiments is to use observational studies or natural experiments and to use field data to support or refute critical assumptions of hypothesized expectations (e.g., Hilborn and Mangel 1997; Rosenbaum 2002). Predator reduction programs, while not controlled experiments, are expected to reduce densities of apex predators, which can be quantified and thus strengthen inference when testing for apex predator effects (Ford and Goheen 2015).

In this study, we adopted a hypothetico-deductive approach to develop and test falsifiable hypotheses about the influence of an apex predator on an intact guild of nonapex predators. We used the spatial variation in density of an apex predator, the gray wolf, produced by a state-sponsored predator control program in Alaska to estimate the guild-wide responses of mesopredators (coyotes, wolverine [Gulo gulo], Canada lynx [Lynx canadensis], and red foxes) and small predators (American marten [Martes americana]) to apex predator abundance. Among mammalian carnivores, dominance hierarchies arise based on body size and resource overlap (Caro and Stoner 2003). Species closer in body size and resource use are expected to compete more intensively, thus engaging more often in interspecific aggression and killing (Donadio and Buskirk 2006). Wolves are known to suppress coyotes; in turn, coyotes may suppress foxes, felids, and small mustelids through interference and exploitation competition (Paquet 1991; Thurber et al. 1992; Palomares and Caro 1999; Linnell and Strand 2000; Smith et al. 2003). However, coyotes, wolverines, and red foxes may also benefit from wolf presence because they commonly scavenge from wolf kills. Coyotes and wolverines are most likely to compete with wolves due to high overlap in diet and body size. Red foxes, lynx, and marten are least likely to directly compete with wolves due to lower diet overlap and a greater difference in body size (Donadio and Buskirk 2006; Ripple et al. 2011; Levi and Wilmers 2012).

We evaluated two contrasting hypotheses. First, we hypothesized a suppression-driven cascade (fig. $1 \mathrm{~A}$ ). We predicted that an apex predator (wolves) will suppress dominant mesopredators (coyotes and wolverines), resulting in an indirect net benefit to other mesopredators (red foxes and lynx) and small predators (marten). In this suppression-driven system, we further predicted that species negatively associated with wolves would exhibit patterns of fine-scale spatial avoidance in relation to recent wolf activity. Alternatively, we hypothesized a facilitation-driven cascade (fig. $1 B$ ), whereby an apex predator will promote the occurrence of all mesopredators due to carrion provisioning, resulting in an indirect netnegative effect on small predators. In a facilitation-driven system, we further predicted that species positively associated with wolves would exhibit patterns of fine-scale spatial attraction to recent wolf activity. We evaluated our predictions while accounting for the influence of small prey abundance and key habitat characteristics, which can moderate the strength of top-down intraguild interactions (Creel 2001; Elmhagen and Rushton 2007). Although we framed our hypotheses based on the well-studied coyote-mediated mesopredator cascade, our analytical approach allowed us to evaluate the direct effects of wolves on all nonapex predators in our study system, along with the resulting alternative mesopredator cascade pathways. Thus, our study was designed to provide a means to assess evidence of community-level effects resulting from the cascade of positive and negative interactions throughout an entire predator guild.

\section{Methods \\ Study System}

We conducted repeated snow track surveys over two winters in two study areas in interior Alaska —Denali and Susitna 


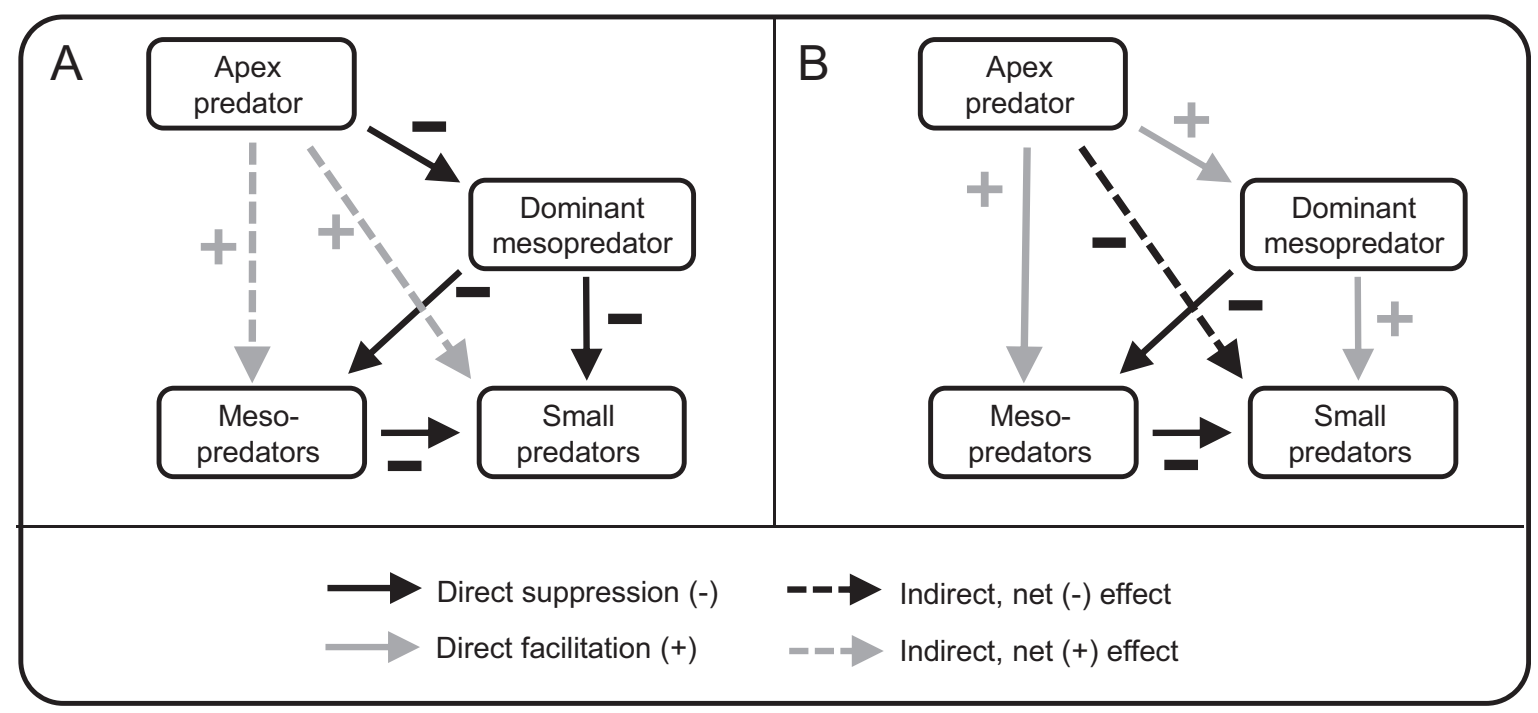

Figure 1: Conceptual diagram of hypothesized suppression and facilitation cascades among apex and nonapex predators. Signed (+/ - ) paths show the hypothesized net interaction effect between two species. $A$, A suppression-driven cascade, whereby the suppression of a competitively dominant mesopredator by an apex predator indirectly benefits other meso- and small predators. $B, A$ facilitation-driven cascade, whereby facilitation of mesopredators leads to indirect suppression of small mesopredators.

(fig. 2). Denali was a 2,000- $\mathrm{km}^{2}$ area overlapping the northeast corner of Denali National Park and Preserve (DNPP), which included $500 \mathrm{~km}^{2}$ of state-managed land known as the Stampede Corridor. Wolves are protected from hunting and trapping within the original park boundary, but they are subject to light harvest in bordering DNPP lands and in the Stampede Corridor. Harvest was not found to impact population dynamics within our study area (Borg et al. 2014); therefore, we considered this population to be naturally regulated. During the two-year study period, wolf density in Denali averaged 7.6 wolves per $1,000 \mathrm{~km}^{2}$ and was considered stable (S. Arthur, DNPP, personal communication).

Susitna, located $200 \mathrm{~km}$ southeast of Denali, was $1,800 \mathrm{~km}^{2}$ of remote land in the upper Susitna River Basin largely managed by the state, with some private and Native land allotments. As part of the larger Nelchina Basin Game Management Unit (GMU 13), the wolf population in Susitna had been subject to $36 \%-80 \%$ annual removal since 2000 . Wolf numbers in portions of GMU 13 are monitored with minimum counts conducted during aerial surveys. Minimum counts in Susitna indicated a minimum density of 1.45 wolves/ $1,000 \mathrm{~km}^{2}$ in 2015 throughout GMU 13 (K. Colson, Alaska Department of Fish and Game, unpublished data). Surveys conducted during the years of our study (2012-2014) were insufficient for a reliable minimum count, but density was likely less than in 2015 given the wolf control during our study (Alaska Department of Fish and Game 2015).

The study region is within a subarctic ecosystem characterized by long, cold winters averaging $-24^{\circ} \mathrm{C}$ and short, mild summers averaging $17^{\circ} \mathrm{C}$. The elevation of the two study areas ranged from 330 to $1,900 \mathrm{~m}$ (Denali, $\bar{x}=653 \pm$ 134 m SD; Susitna, $\bar{x}=916 \pm 148$ m SD). Predominant plant communities were boreal and mixed deciduous forest (Picea spp., Betula spp., and Populus tremuloides), high- and low-elevation tussock and low shrub tundra, shrubs (Salix spp. and Alnus spp.), and alpine graminoid meadows. The two study areas were generally similar in composition of open-cover versus closed-cover habitat types; however, Susitna was characterized by slightly more low shrubs and less tundra compared to Denali (fig. A1, available online). Moose (Alces alces), caribou (Rangifer tarandus), and Dall sheep (Ovis dalli dalli) were the only ungulates. Rodent prey consisted of snowshoe hares (Lepus americanus), red squirrels (Tamiasciurus hudsonicus), five species of voles (Myodes rutilus and Microtus spp.), beavers (Castor canadensis), muskrats (Ondatra zibethicus), and porcupines (Erethizon dorsatum). Avian prey included willow ptarmigan (Lagopus lagopus) and spruce grouse (Falcipennis canadensis).

The terrestrial predator guild consisted of wolves, coyotes, red foxes, Canada lynx, wolverines, American marten, and weasels (Mustela nivalis, Mustela erminea). Coyotes first appeared in Alaska in the early 1900s, and locally abundant populations are now present throughout the state (Parker 1995). Two aquatic mesopredators, river otters (Lontra canadensis) and mink (Neovision vison), were also present in both areas, but their distributions were restricted to riparian corridors, and they were rarely encountered during track surveys. Although brown bears (Ursus arctos) and black bears 


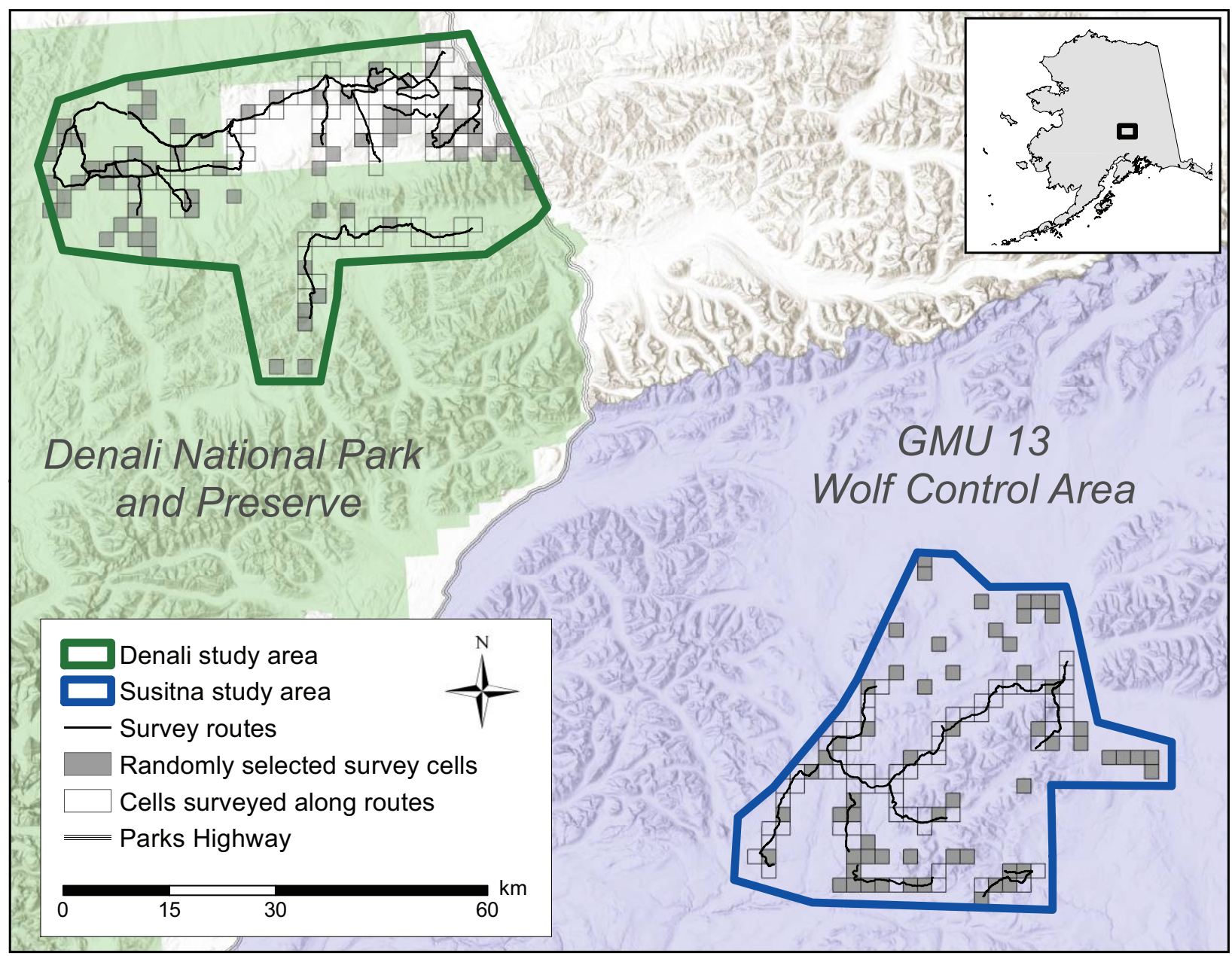

Figure 2: Denali and Susitna study areas in interior Alaska (lat. $63^{\circ} 0^{\prime}-63^{\circ} 47^{\prime} \mathrm{N}$, long. $148^{\circ} 11^{\prime}-149^{\circ} 12^{\prime} \mathrm{W}$ ). Sampling grids were surveyed winter 2013 and 2014 for snow tracks of wolves, mesopredators, and prey.

(U. americanus) were present in both sites and are expected to influence scavenger attendance at wolf kills (Allen et al. 2015), bears were not considered in this analysis because data were collected while bears were hibernating. Fur trapping activity was comparable between study areas, with $2-3$ active traplines observed by field crews in each area. Overall anthropogenic activity was low in both areas, and winter transportation was restricted to snowmobile, dog team, or small aircraft.

\section{Snow Track Surveys}

We conducted snow track surveys for wolves, four mesopredators (coyotes, lynx, red foxes, and wolverine), one small predator (marten), and small prey (snowshoe hares, red squirrels, and voles) along transects in randomly selected grid cells in Denali and Susitna from January through March in both 2013 and 2014. We used ArcGIS 10.0 (Environmental Sys- tems Research Institute, Redlands, CA) to superimpose a grid of $4-\mathrm{km}^{2}$ cells over maps of each study area. This cell size represents the average home range size of marten, the smallest predator in our analysis (Buskirk 1983). We reclassified land cover types identified by satellite imagery (Kreig 1987; Boggs et al. 2001) and assigned each grid cell to one of four major habitat types (tundra/meadow, spruce/mixed forest, tall shrub, and low shrub) based on the majority habitat type present in each cell. We randomly selected a total of 100 cells stratified by habitat to survey in 2013 . To increase sample size and maximize efficiency in 2014, we resurveyed cells surveyed in 2013 and also surveyed all cells intercepted along trails traveled en route (fig. 2).

Snow track surveys were conducted by snowmobile, dog team, or on foot using ski or snowshoes. To estimate detection probabilities, all cells were surveyed a minimum of two times as either temporally replicated line transects or spatially replicated square transects, depending on terrain and permit- 
ted snowmobile access. Linear transects were surveyed along preexisting and temporary trails established and maintained for the duration of the study. When possible, trails were routed to bisect the grid cell with a minimum distance of $2 \mathrm{~km}$. In cases where this was not possible due to terrain or vegetation, trail distance was a minimum of $1 \mathrm{~km}$ and passed as close to the center of the grid cell as possible. Each individual track survey within a given cell corresponded to a single temporal replicate. For cells surveyed as square transects, observers traveled along a 4-km square-shaped transect by ski, snowshoes, or snowmobile. Each $1 \mathrm{~km}$ side of the square represented one spatial replicate, for a total of four replicates surveyed in a single tracking session.

Snow track surveys were conducted a minimum of $24 \mathrm{~h}$ after a track-obliterating snowfall to allow for track accumulation. We field identified the species of each carnivore track detected and assigned maximum age of track based on timing of snowfalls and surveys. Snow depth and snow penetrability (i.e., fluffiness) were recorded at 500-m intervals along each transect and averaged for each survey cell. Snow penetrability was measured by releasing a 200 -g cylinder weight (diameter $=8.2 \mathrm{~cm}$, height $=4.2 \mathrm{~cm}$ ) from a height of $50 \mathrm{~cm}$ above the snow surface and measuring the depth it sank into the snow (Kolbe et al. 2007). Prey tracks of each prey species were tallied over 500-m intervals and converted to tracks per kilometer, adjusted for the number of days since last snowfall. The number of hare, squirrel, and vole tracks per kilometer were averaged across all repeat surveys for each survey cell each year.

\section{Data Analysis Approach}

We used an integration of occupancy models (MacKenzie et al. 2005) and structural equation modeling (SEM; Grace 2006) to analyze our data. The data for this analysis is available in the Dryad Digital Repository: http://dx.doi.org/10 $.5061 /$ dryad.tj590 (Sivy et al. 2017). Snow track data were first used to estimate detection and occupancy probabilities for all predators. Occupancy probabilities were then inputted into an SEM. While recent developments in multispecies occupancy models enable examination of species interactions (Richmond et al. 2010; Burton et al. 2012; Bailey et al. 2014), these analyses remain limited to inferences regarding species pairs rather than a suite of interacting species. SEM provides a multivariate framework for simultaneously estimating the relative strengths of a set of hypothesized interaction pathways, with the ability to isolate and compare direct and indirect effects within systems of interest (Grace 2006). Combining occupancy models with SEM facilitates the assessment of hypotheses concerning mechanistic processes that give rise to patterns of species occurrence while also accounting for imperfect detection (Joseph et al. 2016).
Occupancy Models

Single-season, single-species occupancy models were constructed for each predator species. Occupancy analysis uses repeat presence-absence surveys to provide unbiased estimation of the proportion of sites occupied while accounting for imperfect detection (MacKenzie et al. 2005). The number of occasions was the maximum number of repeat surveys conducted in each cell, with unequal replicates between cells treated as missing data (MacKenzie et al. 2005). Occupancy probability, $\psi$, was modeled with study area (AREA) and survey year (YR) as grouping variables. No other covariates were used to model $\psi$ because these factors (i.e., wolf and mesopredator presence, prey abundance, snowpack) were included in the SEM analysis. Detection probability for all species was modeled with the logit link and the covariates survey method (METH), distance surveyed (DIST), days since last snowfall (DSS), observer team (OBS), and year (YR). Goodness of fit for the global detection model was assessed with the Pearson's $\chi^{2}$ test using 10,000 parametric bootstraps of the overdispersion parameter, $\hat{c}$ (MacKenzie and Bailey 2004). Speciesspecific-derived occupancy probabilities for each cell year were estimated in PRESENCE 6.7 (Hines 2009). Because sampling resolution was less than the average home range size for all species except marten, we interpreted occupancy probabilities as probabilities of use rather than true occupancy (Kendall et al. 2013).

\section{SEM Analysis}

Cell-specific occupancy probabilities for the six predators were used in an SEM analysis. We included cell-specific estimates of average snow depth, average snow compaction, average prey tracks per kilometer, and proportion of closed canopy habitat to account for the influence of prey, snowpack, and habitat on predator occupancy probabilities. Average tracks per kilometer for each prey species was log transformed and inputted in the SEM as tracks per kilometer to meet assumptions of normality (Zar 1999). The average number of prey tracks per cell was considered an index of survey cell-specific prey abundance and inputted to the SEM to account for differences in prey abundance that would not be captured had we used prey occupancy estimates. To control for the effects of habitat in the SEM, we grouped the percent cover of predominant habitat types in each cell identified from satellite imagery as either open (tundra and low shrub, which was often snow covered in winter) or closed (spruce and deciduous forest, and tall shrubs). We included closed habitat in the SEM to estimate its effect and omitted open habitat (the predominant habitat; fig. A1), thus implying open habitat as the baseline condition. Remaining study area effects were accounted for by including the binary variable study area, whereby $1=$ Denali (naturally regulated wolf densities) and $0=$ Susitna 
(wolf densities reduced by predator control). We assumed these remaining differences between study areas to be a result of wolf management, as study areas were similar in all other factors most likely to influence predator occurrence (see study area description).

We specified an initial, system-wide model based on $(a)$ our hypotheses, (b) knowledge of predators' life history, and (c) documented predator interactions in boreal ecosystems (fig. 3). Interactions with little or no basis in the literature (e.g., wolverine to coyote) were not included in our starting model, though these paths would be identified during the model evaluation process should they represent a substantial residual relationship. For interpretability of the finalized model, we present standardized path coefficients (Grace and Bollen 2005). We used a global estimation approach to SEM, which compares the covariance matrix implied by paths among variables specified in the a priori model to the observed covariance relations. Maximum likelihood techniques were used for parameter estimation. Overall model data fit was evaluated with Pearson's $\chi^{2}$ test, using $P<.05$ to indicate inconsistencies between the observed and model-implied covariance matrices (West et al. 2012). When biologically justified, model paths were added as necessary to achieve adequate fit based on modification indexes (MI). The signifi- cance of parameters was evaluated at $\alpha=0.05$, unless otherwise specified. To further assess whether within-study area patterns were consistent with the findings of the system-wide SEM, we evaluated submodels for each study area. Because of the complexity of the full model (46 estimated paths) and reduced sample size of study area submodels (Denali $=173$, Susitna $=127$ ), the submodels included only significant paths identified in the full model to keep the ratio of estimated paths per sample unit below one in five (Grace et al. 2015). All SEM analyses were conducted using AMOS software (IBM SPSS 22.0.0).

\section{Wolf Cluster Analysis}

In the Denali study area, a concurrent wolf monitoring program conducted by the National Park Service was used to assess fine-scale spatiotemporal attraction and avoidance patterns between nonapex predators and wolves. Wolves were captured each spring and fall, and GPS-enabled radio collars were fitted on 1-2 wolves in each wolf pack in DNPP (Meier 2009). GPS locations from seven wolves in four packs overlapping the Denali study area between November-April 2013 and 2014 were used to assess the influence of wolf activity clusters on detections of meso- and small predators. Clusters

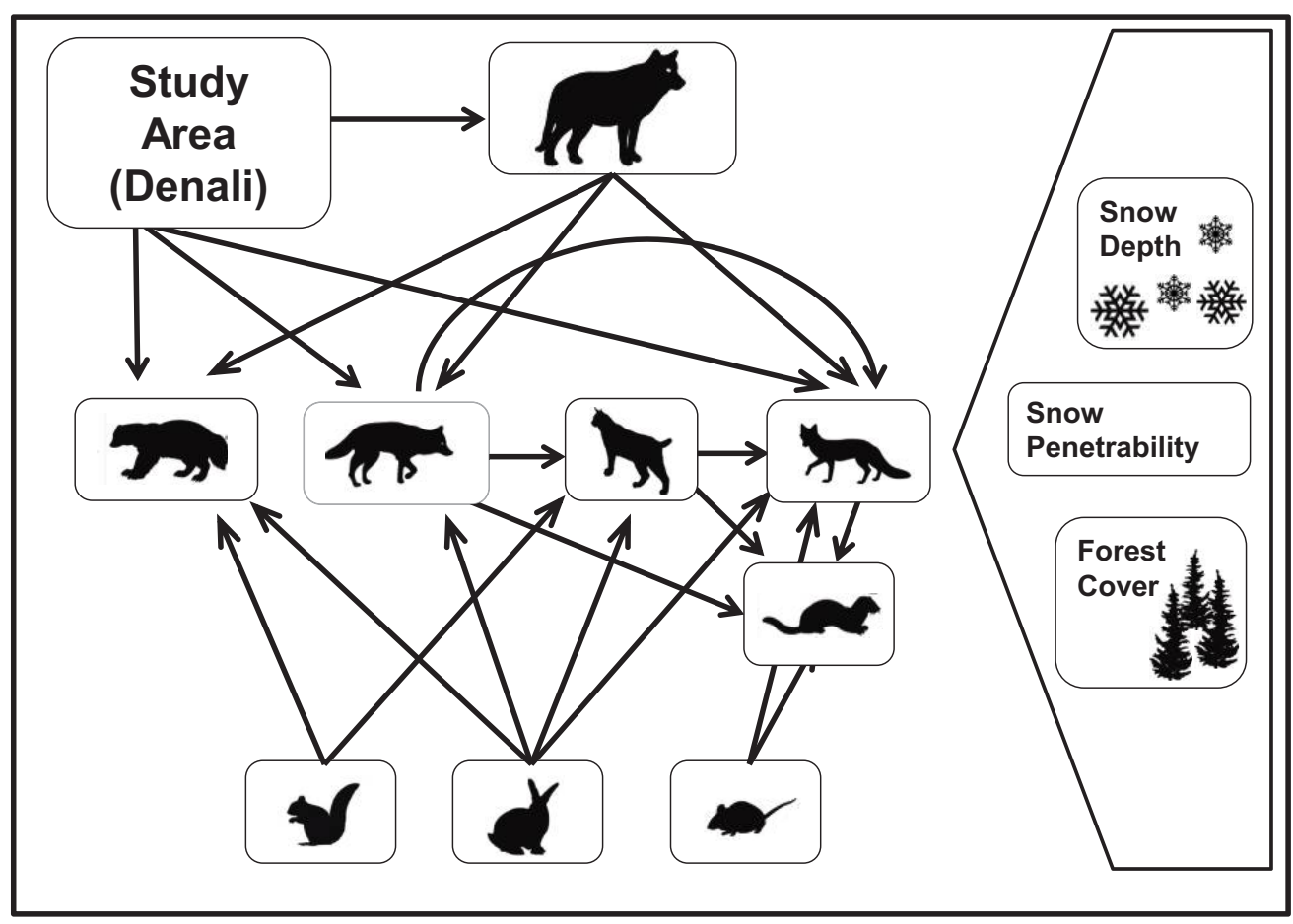

Figure 3: A priori model illustrating all hypothesized pathways evaluated in the initial structural equation model. Relationships were evaluated among wolves (top, center), mesopredators (from left to right, wolverines, coyotes, lynx, and red foxes), small predators (marten), and prey ( from left to right, red squirrels, snowshoe hares, and voles). The influence of three habitat variables (snow depth, snow penetrability, and proportion of forested cover) on each of the six predators was accounted for and estimated in our model (species-specific habitat paths are omitted from diagram for visual clarity). Study area represents the landscape-scale effect related to wolf control (see "Methods" for details). 
were identified using a Python programming algorithm (Python Software Foundation, https://www.python.org/) developed to identify groups of successive GPS locations for kill site analysis (Knopff et al. 2009). We modified the algorithm search radius to include points within a $300-\mathrm{m}$ radius, based on attributes of wolf kill sites reported in similar northern systems (Sand et al. 2005; Lake et al. 2013). Ground truthing the complete cluster data set was beyond the scope of our study, and the cluster data set was expected to overrepresent the number of actual kill sites given that an unknown number of clusters likely included resting areas and failed predation attempts. We therefore considered clusters as activity centers only. We calculated the number of days elapsed between cluster initiation and each individual snow track survey and excluded from analysis any clusters that occurred after cell surveys were conducted. The resulting clusters were mapped in ArcGIS, and the distance of the nearest cluster to each survey cell was calculated. In 2014, five cluster sites identified by the algorithm were investigated, and ungulate kills were detected at three sites. Carcasses detected opportunistically while snow tracking $(n=6)$ were identified post hoc by the cluster algorithm. Remotely triggered trail cameras (Reconyx, model PC900) were placed at these 11 carcass sites to document scavenging activity.

We tested for the effect of distance, days, and the interaction of distance and days since nearest wolf cluster on the presence of meso- and small predator tracks detected during each snow track survey in a given survey cell. To do so, we fitted a generalized linear mixed effects model (GLMM) with a binomial distribution using the Laplace approximation, and we used the Wald's $Z$ test to examine the effect of distance or days since cluster on mesopredator detections (Bolker et al. 2008). We applied a $Z$ transformation to distance (zDIST) and days (zDAYS) to meet assumptions of normality. Survey cell ID was included as a random effect in our model, and zDAYS, zDIST, and their interaction were included as fixed effects. The GLMM interaction model for wolverine and marten failed to converge, and we therefore analyzed detection data for these species as generalized linear models using a binomial distribution and no random effect. Analyses were performed using the lme4 package in $\mathrm{R}$ (Bates et al. 2015).

\section{Results \\ Snow Track Surveys}

From January through March in 2013 and 2014, we surveyed $520 \mathrm{~km}$ of trail intersecting a total of 300 survey cells (Denali, $315 \mathrm{~km}, n=173$ cells; Susitna, $208 \mathrm{~km}, n=127$ cells). Each cell was surveyed between two and nine times per winter $(\bar{x}=3.46)$ with an average 19.4 days between repeat surveys. Tracks per kilometer per day were higher in Denali for wolves, coyotes, and lynx, whereas red fox, wolverine, and marten track counts were higher in Susitna (table A1; tables A1-A5 available online). Prey abundance was generally low both years throughout both study sites, and Susitna had fewer tracks per kilometer per day for hares, voles, and red squirrels than Denali (table A1). Snow depth was greater in Susitna $(\bar{x}=55.05 \pm 1.70 \mathrm{~cm})$ compared to Denali $(\bar{x}=28.27 \pm 1.12 \mathrm{~cm})$. Snow penetrability was similar between study areas (Denali, $\bar{x}=6.29 \pm 0.18 \mathrm{~cm}$; Susitna, $\bar{x}=6.43 \pm 0.28 \mathrm{~cm})$.

\section{Occupancy Models}

All focal species (wolves, coyotes, lynx, red foxes, wolverines, and marten) were detected in both study areas. We used occupancy estimates from the global detection model $\psi$ (AREA + YR), $P$ (METH + DIST + DSS + OBS + YR) for coyotes, lynx, red foxes, wolverine, and marten. The global detection model did not converge for wolves, likely due to sparse detections in Susitna. We therefore used Akaike information criterion model selection (Burnham and Anderson 2002) to identify the highest-ranked detection model to converge among a candidate set of models that included all combinations of detection covariates. The top-ranking detection model for wolves that converged was $\psi$ (AREA + YR), P (METH + DIST). A bootstrap goodness-of-fit test indicated adequate model fit $(\hat{c}<1.0$ or $\sim 1)$ for the final models for all predators $(\hat{c}$ : coyotes $=1.0821$, red fox $=0.494$, lynx $=0.233$, marten $=0.11$, wolverine $=0.625$, wolf $=0.156)$. The average cell-specific occupancy probability for wolves was lower in Susitna, where wolves were subject to predator control $(\psi=0.233 \pm 0.0912 \mathrm{SE})$, compared to Denali, where wolves occurred at naturally regulated densities $(\psi=$ $0.882 \pm 0.17 \mathrm{SE})$.

\section{SEM Fit Results}

We resolved initial lack of fit in our a priori full model $\left(\chi^{2}=47.803, \mathrm{df}=15, P<.001\right)$ by correlating errors between voles and wolves $(\mathrm{MI}=8.047)$ and between wolverines and marten $(\mathrm{MI}=4.751)$, and including directed paths from wolves and study area to marten $(\mathrm{MI}=4.347$, 8.366). The final system-wide model (fig. 4) showed close fit to the observed data $\left(\chi^{2}=14.516, \mathrm{df}=11, P=.206\right)$ and explained $11 \%-61 \%$ of variation in occupancy probabilities of predators. Correlations among prey abundance, snow characteristics, and habitat were low ( $r \leq 0.55$; table A2).

\section{Carnivore Cascades}

Study area significantly predicted occurrences of wolves (table 1 , standardized path coefficient $=0.537$; table A3). At the landscape scale across study areas, occurrence probabilities for the entire guild of nonapex predators were lower in the Denali study area, where wolves were abundant, com- 


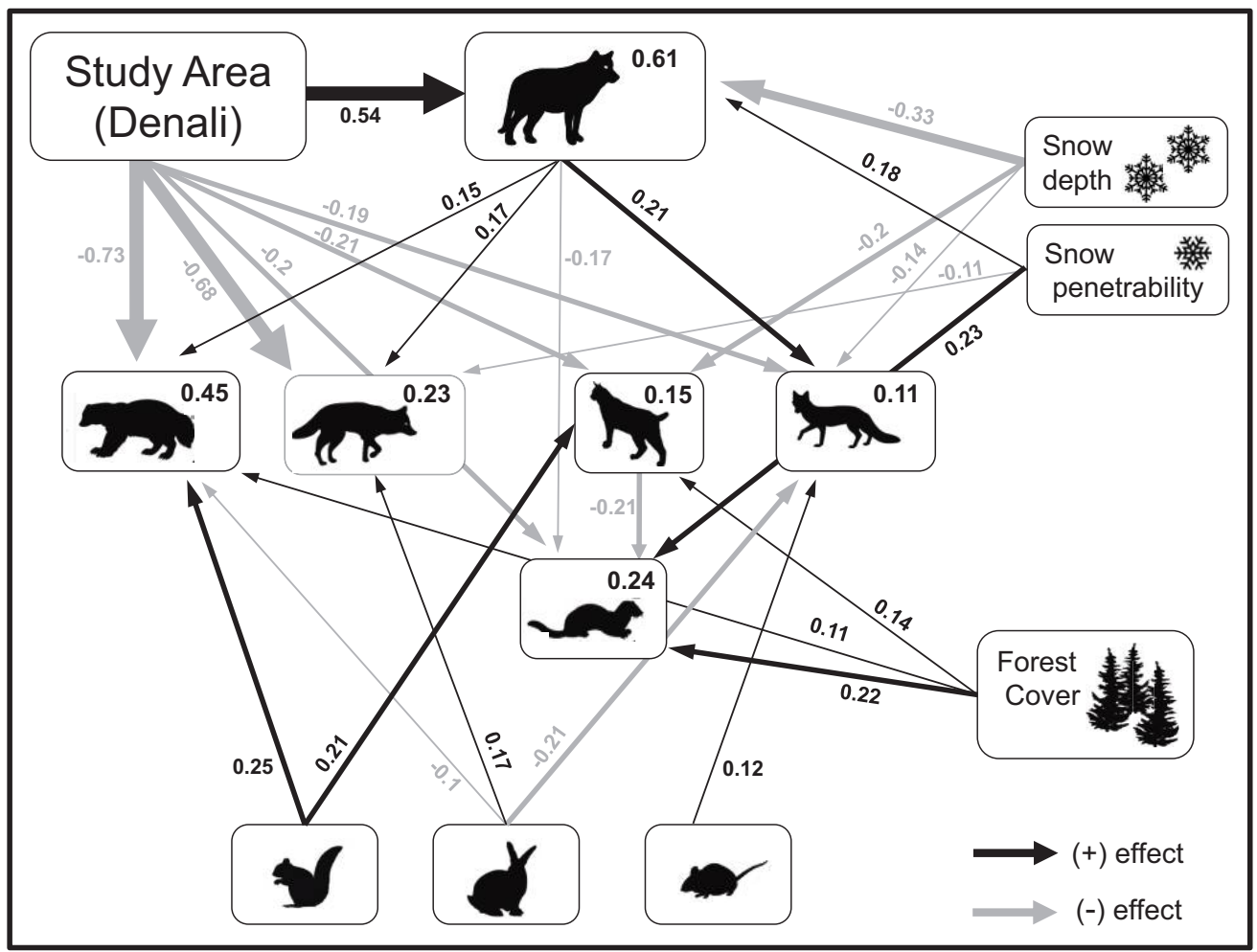

Figure 4: Finalized structural equation model (SEM) evaluating the occurrence of nonapex predators in response to an apex predator, while accounting for prey and habitat characteristics. Values in the upper-right corner of species' boxes indicate variance $\left(R^{2}\right)$ in occupancy probabilities explained by final SEM. Arrow thickness and values along arrows represent the relative magnitudes of significant, standardized path coefficients (table 1). Indirect pathways are the product of two or more direct paths connected through a third variable (e.g., snow depth $\rightarrow$ lynx $\rightarrow$ marten). Nonsignificant paths (table A3) were retained in the final SEM but have been omitted from this diagram for visual clarity.

pared to the Susitna study area, where wolf numbers were reduced (table 1, direct effects of study area). The strongest responses were from coyotes $(-0.677)$ and wolverines $(-0.727)$. In contrast, at the local scale within study areas, all nonapex predators except marten were positively associated with wolves (table 1, direct effects of wolf). Although the presence of wolves appeared to promote coyotes at local scales (0.173), the weak, nonsignificant path coefficients between coyotes and red foxes (0.018), lynx (0.053), and marten $(-0.051)$ did not support the existence of a coyotemediated cascade. The effects of study area and local wolf presence on coyotes accounted for only a marginal proportion of the indirect effects of wolves on other mesopredators (table 2). The only significant associations among the nonapex predators occurred between lynx and marten $(P<.001$; $-0.214)$.

\section{Relationships with Prey, Snow, and Habitat}

Within each study area, coyotes and foxes had a significant, positive relationship with wolves of similar or greater magnitude than the response to each species' prey (table 1). Hares were a significant predictor of coyote occurrence (0.167), yet the positive association between coyotes and wolves was slightly stronger (0.173). Red foxes exhibited a stronger response to wolf occurrence $(0.211)$ than voles $(0.115)$, their primary prey (Sivy 2015). Wolverines were also positively associated with local-scale wolf occurrence (0.147); however, red squirrels remained their strongest predictor (0.249). Lynx also responded positively to local wolf occurrence (0.137), but this path was not significant in the model and lynx were more strongly predicted by red squirrels (0.208). Snowshoe hares had a surprisingly weak effect on lynx occurrence (0.02). Marten responded positively to voles (0.089), yet the negative effects of lynx $(-0.214)$ and local occurrence of wolves $(-0.166)$ on marten were stronger.

Of all the predators, wolves exhibited the strongest relationship with snowpack and favored shallow, fluffy snow (snow depth $=-0.325$, snow penetrability $=0.179$ ). Snow depth was a negative predictor for lynx $(-0.2)$. Snow penetrability was the strongest predictor for marten (0.232). Snow characteristics did not significantly influence occurrences of any other mesopredators. Although the direct effects of snow conditions were comparatively weak for nearly all the non- 
Table 1: Standardized coefficients for direct, indirect, and total paths in the final structural equation model

\begin{tabular}{|c|c|c|c|c|c|c|c|c|c|c|c|}
\hline & $\begin{array}{l}\text { Study } \\
\text { area }\end{array}$ & Wolf & Coyote & Lynx & $\begin{array}{l}\text { Red } \\
\text { fox }\end{array}$ & Hare & Squirrel & Vole & $\begin{array}{l}\text { Snow } \\
\text { depth }\end{array}$ & $\begin{array}{c}\text { Snow } \\
\text { penetrability }\end{array}$ & $\begin{array}{l}\text { Closed } \\
\text { habitat }\end{array}$ \\
\hline \multicolumn{12}{|l|}{ Direct effects: } \\
\hline Wolf & $.537^{*}$ & $\ldots$ & $\ldots$ & $\ldots$ & $\ldots$ & $\ldots$ & $\ldots$ & $\ldots$ & $-.325^{*}$ & $.179^{*}$ & -.009 \\
\hline Coyote & $-.677^{*}$ & $.173^{*}$ & $\ldots$ & $\ldots$ & $\ldots$ & $.167^{*}$ & $\ldots$ & .039 & -.074 & $-.11^{+}$ & .049 \\
\hline Lynx & $-.212^{*}$ & .137 & .053 & $\ldots$ & $\ldots$ & .02 & $.208^{*}$ & $\ldots$ & $-.2^{*}$ & .036 & $.139^{*}$ \\
\hline Red fox & $-.194^{+}$ & $.211^{*}$ & .018 & -.087 & $\ldots$ & $-.208^{*}$ & $\ldots$ & $.115^{+}$ & $-.143^{+}$ & .053 & -.061 \\
\hline Wolverine & $-.727^{*}$ & $.147^{*}$ & $\ldots$ & $\ldots$ & $\ldots$ & $-.097^{+}$ & $.249^{*}$ & $\ldots$ & .06 & -.047 & $.108^{*}$ \\
\hline Marten & $-.199^{*}$ & $-.166^{*}$ & -.051 & $-.214^{*}$ & -.051 & $\ldots$ & $\ldots$ & .089 & -.03 & $.232^{*}$ & $.215^{*}$ \\
\hline \multicolumn{12}{|l|}{ Indirect effects: } \\
\hline Wolf & $\ldots$ & $\ldots$ & $\ldots$ & $\ldots$ & $\ldots$ & $\ldots$ & $\ldots$ & $\ldots$ & $\ldots$ & $\ldots$ & $\ldots$ \\
\hline Coyote & .093 & $\ldots$ & $\ldots$ & $\ldots$ & $\ldots$ & $\ldots$ & $\ldots$ & $\ldots$ & -.056 & .031 & -.002 \\
\hline Lynx & .043 & .009 & $\ldots$ & $\ldots$ & $\ldots$ & .009 & $\ldots$ & .002 & -.052 & .02 & .001 \\
\hline Red fox & .118 & -.01 & -.005 & $\ldots$ & $\ldots$ & .001 & -.018 & .001 & -.049 & .032 & -.013 \\
\hline Wolverine & .08 & $\ldots$ & $\ldots$ & $\ldots$ & $\ldots$ & $\ldots$ & $\ldots$ & $\ldots$ & -.048 & .026 & -.001 \\
\hline Marten & -.02 & -.05 & -.012 & .004 & $\ldots$ & -.004 & -.044 & -.008 & .124 & -.042 & -.027 \\
\hline \multicolumn{12}{|l|}{ Total effects: } \\
\hline Wolf & .537 & $\ldots$ & $\ldots$ & $\ldots$ & $\ldots$ & $\ldots$ & $\ldots$ & $\ldots$ & -.325 & .179 & -.009 \\
\hline Coyote & -.584 & .173 & $\ldots$ & $\ldots$ & $\ldots$ & .167 & $\ldots$ & .039 & -.131 & -.079 & .047 \\
\hline Lynx & -.169 & .147 & .053 & $\ldots$ & $\ldots$ & .029 & .208 & .002 & -.252 & .056 & .141 \\
\hline Red fox & -.075 & .202 & .013 & -.087 & $\ldots$ & -.207 & -.018 & .115 & -.193 & .084 & -.075 \\
\hline Wolverine & -.647 & .147 & $\ldots$ & $\ldots$ & $\ldots$ & -.097 & .249 & $\ldots$ & .012 & -.021 & .107 \\
\hline Marten & -.219 & -.216 & -.063 & -.21 & -.051 & -.004 & -.044 & .081 & .094 & .19 & .188 \\
\hline
\end{tabular}

apex predators, the indirect effects of snow conditions, mediated through other predators, accounted for $20 \%-40 \%$ of the total or net effect of snow on nonapex predators (table 1, total effects).

Closed-cover habitat (spruce and deciduous forest and tall shrubs) was a significant, positive predictor for lynx (0.139), wolverines (.108), and marten (0.215); however, the predictive strength of prey and/or wolves were stronger for all these species. All three canids exhibited weak, nonsignificant associations with closed-cover habitat. The indirect effects of closed-cover habitat, mediated through other predators, were negligible for all nonapex predators; however, the strength of the direct positive association of marten with closed-cover habitat was reduced $14 \%$ by indirect effects.

Of all the significant predictors, wolves had the strongest net total effect (direct plus indirect effect) on occurrence for coyotes, red foxes, and marten. The net effect of snow depth was the strongest predictor for lynx, and the net effect of squirrel abundance was the strongest predictor for wolverines.

Table 2: Strength of direct versus indirect effects of wolves on mesopredators, moderated through coyotes

\begin{tabular}{lcccccc}
\hline & \multicolumn{3}{c}{ Direct effects } & & \multicolumn{2}{c}{ Indirect effects } \\
\cline { 2 - 3 } & Study area & Local wolf & Coyote & & Study area $\rightarrow$ coyote & Local wolf $\rightarrow$ coyote \\
\hline Coyote & -.667 & .173 & $\ldots$ & & $\ldots$ & $\ldots$ \\
Lynx & -.212 & .137 & .053 & & -.011 & .007 \\
Red fox & -.194 & .211 & .018 & & -.003 & .004 \\
Wolverine & -.727 & .147 & $\ldots$ & $\ldots$ & $\ldots$ \\
Marten & -.199 & -.166 & -.051 & & .01 & .008 \\
\hline
\end{tabular}

Note: Direct effects are the standardized path coefficients in the structural equation model (table 1). Indirect effects are the product of the direct effects pathway and the pathway indicated in the column headings. Ellipses indicate paths not evaluated in the model. 


\section{Study Area Submodels}

Model fit was improved for the Denali submodel by including a direct path from voles to wolverines $\left(\chi^{2}=35.325\right.$, $\mathrm{df}=28, P=.161)$. We improved fit in the Susitna submodel by including a direct path from closed habitat to red foxes $\left(\chi^{2}=16.661, \mathrm{df}=28, P=.955\right)$. Patterns of association between wolves and nonapex predators in the Denali submodel were consistent with findings of within-studyarea effects in the full model, yet only significant for the canids (table A4). In the Susitna submodel, associations between wolves and nonapex predators were generally weaker in both strength and significance level compared to the full model (table A5).

\section{Wolf Cluster Analysis}

A total of 39 clusters made by seven wolves from four wolf packs were identified. The distance of clusters to survey cells ranged from 0 (within the survey cell) to $18.4 \mathrm{~km}(\bar{x}=6.3 \mathrm{~km})$. An average of 18.8 days (range 1-78 days) elapsed between clusters and surveys. Proximity to wolf clusters in space and time had varying effects on detections of the six predators (table 3). For wolves, detections decreased with distance when clusters were more recent, as evidenced by a significant interaction between zDAYS and zDIST (table 3). Detection of coyotes decreased with distance to wolf clusters, and there was no effect of days since cluster (table 3 ). There was a marginal negative effect $(P=.10)$ of distance to clusters on wolverine detections and a weak interaction with days $(P=.13)$, suggesting that distance had a slightly stronger negative effect on wolverine detections for older clusters. Red fox, lynx, and marten detections were not affected by distance to or days since wolf clusters (table 3). Of the photographs taken by remote cameras at 11 carcasses, there were 4,301 photographs of wolverines, 1,009 of coyotes, 346 of red foxes, 63 of lynx, and none of marten.

\section{Discussion}

Our findings imply that apex predators may have a more positive, guild-wide influence on mesopredators than previously thought, presenting an alternative to the widely held mesopredator release scenario, whereby apex predators influence nonapex predators through a suppression cascade. The local-scale positive associations and landscape-scale neg-

Table 3: Parameter estimates for wolf cluster analysis

\begin{tabular}{|c|c|c|c|c|c|c|c|}
\hline Species & Variance & SD & Fixed effect & Estimate & SE & $z$ & $\operatorname{Pr}(>|z|)$ \\
\hline \multirow[t]{4}{*}{ Wolf $^{a}$} & .4477 & .6691 & (Intercept) & -2.497 & .236 & -10.573 & $<.001^{*}$ \\
\hline & & & zDIST & -.607 & .147 & -4.135 & $<.001^{*}$ \\
\hline & & & zDAYS & .316 & .168 & 1.877 & $.0605^{+}$ \\
\hline & & & zDIST $^{*}$ zDAYS & .436 & .137 & 3.181 & $.0015^{*}$ \\
\hline \multirow[t]{4}{*}{ Coyote $^{\mathrm{a}}$} & 2.795 & 1.672 & (Intercept) & -3.453 & .456 & -7.579 & $<.001^{*}$ \\
\hline & & & zDIST & -.883 & .201 & -4.401 & $<.001^{*}$ \\
\hline & & & zDAYS & -.293 & .205 & -1.426 & .154 \\
\hline & & & zDIST $^{*} \mathrm{zDAYS}$ & -.189 & .151 & -1.252 & .211 \\
\hline \multirow[t]{4}{*}{ Red fox ${ }^{a}$} & .5093 & .7137 & (Intercept) & -2.143 & .211 & -10.139 & $<.001^{*}$ \\
\hline & & & zDIST & .201 & .15 & 1.345 & .179 \\
\hline & & & zDAYS & -.059 & .136 & -.432 & .666 \\
\hline & & & zDIST $^{*} z D A Y S$ & .146 & .132 & 1.111 & .267 \\
\hline \multirow[t]{4}{*}{$\operatorname{Lynx}^{a}$} & 2.441 & 1.562 & (Intercept) & -3.226 & .41 & -7.873 & $<.001^{*}$ \\
\hline & & & zDIST & -.236 & .196 & -1.202 & .229 \\
\hline & & & zDAYS & .245 & .184 & 1.329 & .184 \\
\hline & & & zDIST $^{*} \mathrm{zDAYS}$ & .045 & .155 & .289 & .772 \\
\hline \multirow[t]{4}{*}{ Wolverine $^{\mathrm{b}}$} & & & (Intercept) & -2.903 & .191 & -15.165 & $<.001^{*}$ \\
\hline & & & zDIST & -.279 & .171 & -1.629 & .103 \\
\hline & & & zDAYS & -.06 & .194 & -.31 & .757 \\
\hline & & & zDIST $^{*} z D A Y S$ & -.221 & .146 & -1.512 & .13 \\
\hline \multirow[t]{4}{*}{ Marten $^{\mathrm{b}}$} & & & (Intercept) & -4.217 & .355 & -11.887 & $<.001^{*}$ \\
\hline & & & zDIST & .23 & .382 & .601 & .548 \\
\hline & & & zDAYS & .053 & .347 & .152 & .879 \\
\hline & & & zDIST ${ }^{*} z D A Y S$ & -.1 & .319 & -.315 & .753 \\
\hline
\end{tabular}

${ }^{a}$ Parameters estimated from generalized linear mixed effects models; random effect $=$ cell ID, number of observations $=594$, number of groups $=143$.

${ }^{b}$ Parameters estimated from generalized linear model with no random effects.

${ }^{+} P<.10$.

${ }^{*} P<.05$. 
ative associations we observed among wolves and nonapex predators leads us to suggest that facilitation and suppression can jointly drive occurrence patterns of predators. Positive associations among predators could obfuscate suppressioninduced cascades at fine spatial scales while influencing the strength of suppression at coarse spatial scales. Conservation and management actions seeking to restore or reduce apex predator populations should consider the potential for apex predators to have a direct and facilitative influence on more than just a single competitively dominant mesopredator. These results highlight the importance of including facilitative interactions such as intraguild food provisioning in models of predator community dynamics.

Wolf presence in both study areas was sufficient to elicit significant responses from nonapex predators, yet there was minimal evidence of a cascade from mesopredators to small predators at either the local or landscape scale. The weak effect of coyotes on red foxes, lynx, and marten may have been due to low densities of mesopredators and prey. Mesopredator densities tend to be an order of magnitude lower in northern systems compared to more productive regions at lower latitudes, where as many as 71 coyotes and 91 foxes per $100 \mathrm{~km}^{2}$ are reported (summarized by O'Donoghue et al. 1997b; Pozzanghera 2015). Densities in our study areas ranged from 0.41 to 1.8 coyotes and 1.5 to 2.4 red foxes per $100 \mathrm{~km}^{2}$ (Pozzanghera 2015). Hare populations also remained low since the last peak in 2009, and vole abundance was low in Denali and Susitna (Krebs et al. 2013; Sivy 2015). The association of lynx with red squirrels, rather than hares, in our SEM is consistent with previous documentation of predation on red squirrels as an alternative prey when hares are scarce (O’Donoghue et al. 1997a, 1997b). This low resource state likely contributed to low densities of nonapex predators during this study.

Fluctuations in small mammal abundance are inherent to numerous ecosystems across the globe and can strongly influence the density of both generalist and specialist mesopredators (Korpimaki and Krebs 1996; Ostfeld and Keesing 2000). The effect of resource pulses on predator densities and resource competition can alter the strength of predator cascades, depending on the phase of the resource pulse (Greenville et al. 2014). In boreal ecosystems, snowshoe hares and microtine rodents undergo irruptive boom-bust cycles with 10 - to 25 -fold changes in population density, to which the densities of coyotes, red foxes, and lynx are closely tied (Boutin et al. 1995; Krebs et al. 2001). Competition theory predicts that crashes in small mammal abundance should increase resource competition between sympatric competitors (Pianka 1981). In our study system, predator densities may have already equilibrated in response to low resource availability, which could have reduced encounter rates among competitors, weakened interference competition, and ultimately dampened cascading mesopredator-release effects.
Density thresholds are not generally accounted for in studies of mesopredator release and should be considered for predicting and testing predator cascades. Predator densities are important for determining whether a system is dominated by top-down interaction cascades or by bottom-up resource availability (Elmhagen et. al 2010). The exploitation ecosystem hypothesis (EEH) predicts that low apex predator densities are sufficient for suppressing mesopredators in unproductive systems, whereas higher densities of apex predators are necessary for suppression in productive systems (Oksanen et. al 1981). However, if mesopredator densities are high and apex predator densities remain low, competition within the mesopredator guild could predominate over top-down suppression.

\section{Positive Associations with Wolves}

Rather than the predicted coyote-mediated cascade, we observed positive associations whereby the direct effect of localized wolf presence appeared to promote occurrence of all mesopredators (but not marten, the small predator). For coyotes and red foxes, the positive association was at strengths similar to or greater than that of each species' respective primary prey. These positive associations between mesopredators and wolves could have been due to coincidental habitat selection (i.e., habitat filtering; Weiher and Keddy 1999). If this were the case, wolves and mesopredators should have exhibited significant, similar responses to habitat and snow characteristics. Instead, habitat and snow tended to have opposing effects on wolves versus nonapex predators, or the effects were weak and nonsignificant. Although it is possible that coincidental habitat selection occurred where effects were similar (e.g., the negative effect of snow depth on wolves, lynx, and red foxes), it is unlikely to have led to the strong and consistent space-use patterns we documented given the differences in home range size and resource use among predators (Buskirk 1983; Banci and Harestad 1990; O’Donoghue et al. 1997a; Mech et al. 1998).

We suggest that facilitation via carrion exploitation is a likely explanation for the observed local-scale, positive spaceuse patterns. Carrion is common in the diets of coyotes, red foxes, and wolverines (Gese et al. 1996; Wilmers et al. 2003b; Prugh 2005; van Dijk et al. 2008a; Dalerum et al. 2009; Needham and Odden 2014). Lynx are also known to scavenge during hare declines (Brand et al. 1976; Poole 2003). Analysis of prey remains in coyote and red fox scats collected concurrently with this study showed that carrion accounted for $40 \%-62 \%$ of coyote diet and $10 \%-35 \%$ of red fox diet (Sivy 2015). Large ungulate carcasses could be powerful attractants for a diverse community of mesopredators, luring scavengers into areas of past and present large carnivore activity (Wilmers et al. 2003b; Selva and Fortuna 2007; Cortés-Avizanda et al. 2009; Yarnell et al. 2013). This attraction is likely more 
pronounced where wolves (and, presumably, wolf-provided carrion) are more abundant. Indeed, positive associations with wolves were much stronger for coyotes and red foxes in Denali than in Susitna (table A4), where reduced wolf density may have reduced scavenging benefits below a critical threshold. Although we were unable to ground truth the presence of carcasses at all wolf activity clusters in Denali, our cluster analysis showed that the likelihood of detecting coyotesand, to a lesser extent, wolverines - significantly increased in survey cells within close proximity to wolf clusters. Photo counts of scavengers were also consistent with the strength of local- and landscape-scale wolf effects in the SEM. The tendency for coyotes and wolverines to closely track wolves in our study system could enable them to investigate and exploit areas of concentrated wolf activity. We expected a similar response to clusters from red foxes, yet the coarseness of our cluster analysis may have precluded detection of relatively weak effects.

Carrion subsidies from apex predators present a risky yet predictable food source that could benefit mesopredators, especially during periods of low prey availability. To minimize risk of encounter with wolves, coyotes rely on fine-scale spatial and temporal avoidance to exploit scavenging opportunities (Thurber et al. 1992; Atwood and Gese 2008, 2010; Atwood et al. 2009). After wolf recolonization in northern Montana, coyotes scavenged from and had high home range overlap with wolves during winter months, yet they adjusted daily activity patterns around wolf activity (Arjo and Pletscher 1999). Wolverines similarly exhibit fine-scale spatial partitioning while scavenging from wolves in Norway (Van Dijk et al. 2008b). Fine-scale spatiotemporal partitioning by scavengers could be an important mechanistic link to minimize antagonistic encounters when exploiting carrion from apex predators (Durant 1998; Berger and Gese 2007; Van Dijk et al. 2008a; Broekhuis et al. 2013; Vanak et al. 2013; Swanson et al. 2014).

\section{Comparisons between Study Areas}

We observed a strong, guild-wide negative response to wolves, whereby occupancy probabilities of mesopredators were lower in Denali, where wolves occurred at naturally regulated densities, compared to Susitna, where wolf densities were artificially reduced. The relative strength of top-down versus bottom-up effects in this study system further indicated that study area was the strongest predictor of wolf, coyote, and wolverine occurrence relative to snowpack characteristics and prey, whereas lynx presence remained most strongly predicted by prey. Due to the lack of replication at the landscape scale, it is possible that differences among our two study areas other than wolf abundance, prey abundance, snow characteristics, and habitat type could have contributed to the patterns we observed. However, our sampling units in each of the two study areas were nearby and similar in general topography (see study area description). Anthropogenic use was low in both areas, and trail density and proximity to human settlements did not affect mesopredator occupancy in concurrent analyses (Pozzanghera et al. 2016). Variation in wolf density, due to more than a decade of wolf removal in our Susitna study area, was most likely the predominant factor affecting landscape-scale mesopredator occupancy.

We propose a hypothesis of fatal attraction to explain the opposing guild-wide effects of wolves on mesopredators at landscape and local scales documented in our study. Attraction to carcasses may result in positive local-scale associations among carnivores, but scavenging-related mortality could lead to negative landscape-scale effects of apex predators. Carcasses could act as a magnet for aggressive encounters, with severe consequences for the unsavvy. In the Greater Yellowstone ecosystem, 75\% of aggressive encounters between wolves and coyotes occurred at kill sites (Merkle et al. 2009). Wolves can be a considerable source of mortality; wolf predation accounted for $67 \%$ of radio-collared coyote mortalities on the Kenai Peninsula (Thurber et al. 1992) and 50\% of collared coyote mortalities in Denali and a nearby area in the Alaska Range (L. Prugh, unpublished data; Prugh and Arthur 2015). Likewise, it is not uncommon for wolverines to be killed by wolves and mountain lions (another apex predator that provides carrion subsidies): predation accounted for $18 \%$ of 54 wolverine mortalities reported in 12 studies (Krebs et al. 2004). Although wolves have lower niche overlap with marten and red foxes that also exhibited lower average occupancy probabilities in the Denali study area, co-occurrence of these species in the vicinity of carcasses could elicit a generalized predatory response from wolves when present. Although not testable within our study design, increased time in the vicinity of apex predator kills may escalate risk of intraspecific aggression and killing.

The magnitude of population-level mesopredator suppression by apex predators may depend on the intensity of facilitation (i.e., scavenging) and resource overlap. Interspecific competition is predicted to intensify between species pairs that are similar in body size and have high niche overlap (Donadio and Buskirk 2006), yet carrion provisions from apex predators are regularly exploited by the larger mesopredators. The net facilitative versus suppressive effect of an apex predator on mesopredators may also depend on the particular behavioral and morphological attributes of mesopredators (Allen et al. 2016). The low occupancy probabilities in the wolf-abundant study area compared to the wolf control area was most pronounced for coyotes and wolverines. Of the nonapex predators in our study system, coyotes and wolverines have body sizes most similar to wolves and have highest potential diet overlap with wolves considering use of carrion resources and predation on live ungulates (Mattisson et al. 2011; Prugh and Arthur 2015). Localized cell-specific 

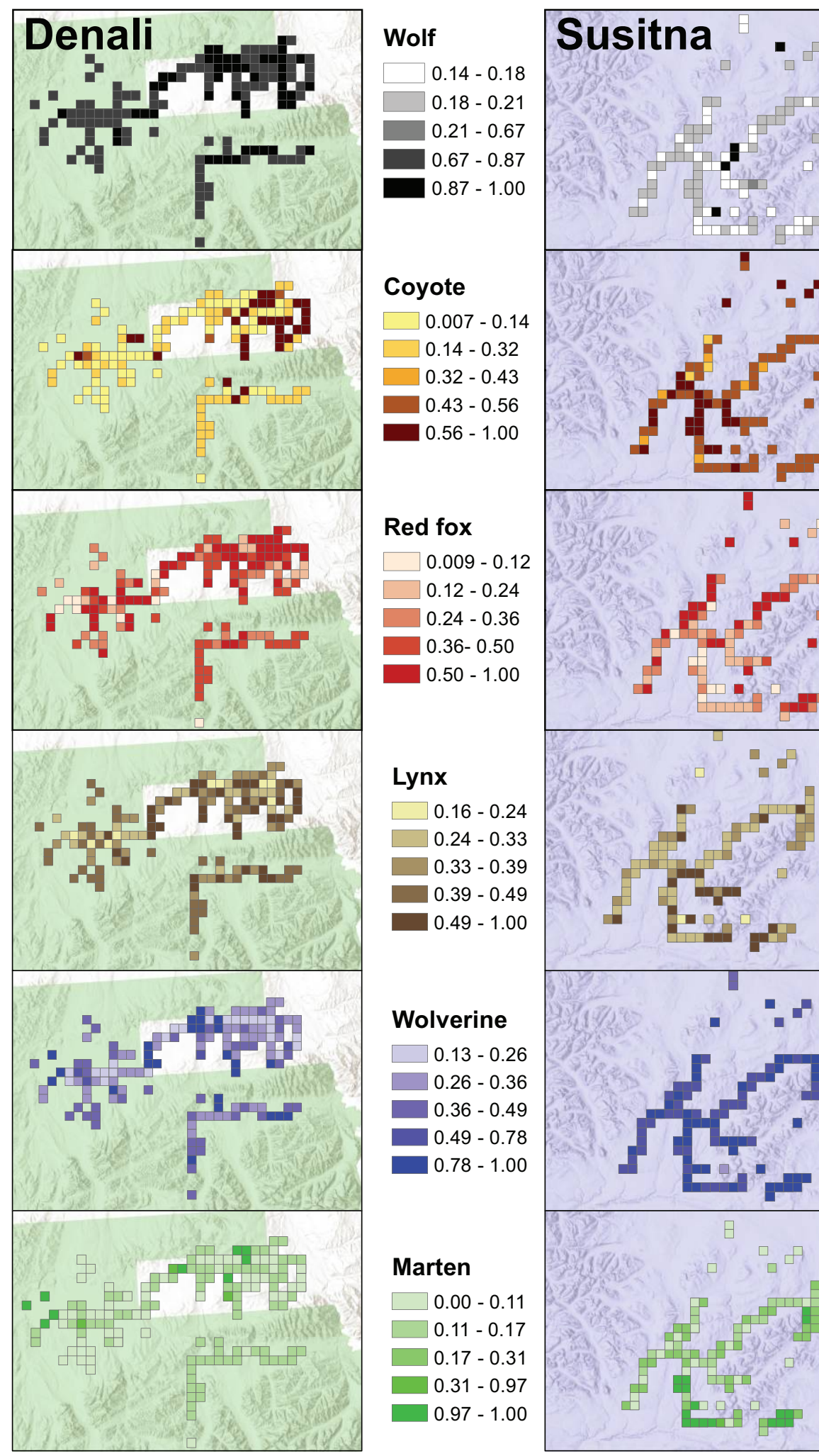

\section{Red fox}

\begin{tabular}{|l|l|}
\hline$\square$ & $0.009-0.12$ \\
$\square$ & $0.12-0.24$ \\
& $0.24-0.36$ \\
& $0.36-0.50$ \\
& $0.50-1.00$
\end{tabular}

Lynx

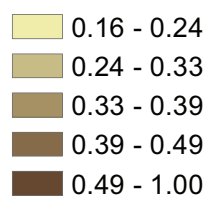

Wolverine

$\square 0.13-0.26$

$0.26-0.36$

$0.36-0.49$

$0.49-0.78$

$0.78-1.00$
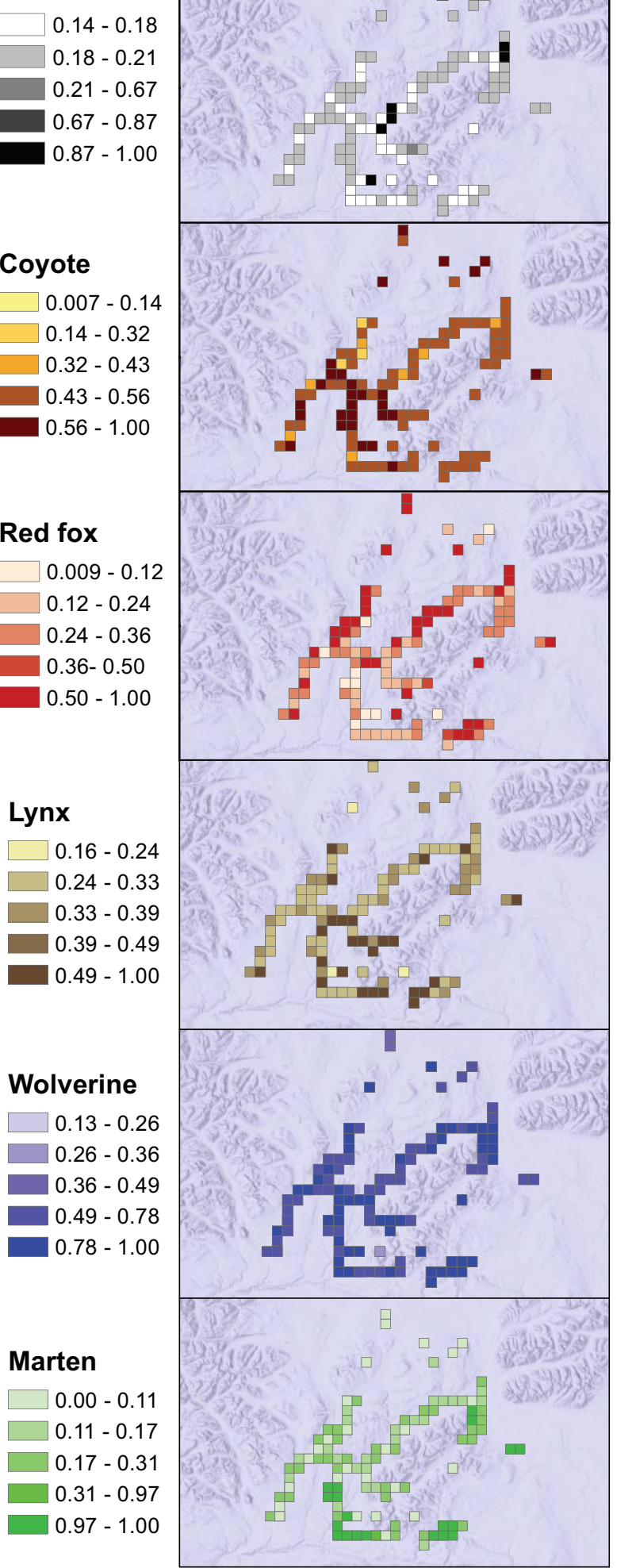

Figure 5: Cell-specific occupancy of wolves, meso-, and small predators in Denali and Susitna, 2013-2014. Legend values represent natural breaks in average occupancy probabilities for each species. 
occupancy probabilities for coyotes and wolverines during this study were more patchily distributed, with a greater cell-tocell variation within the wolf-abundant study area compared to the wolf-control study area (fig. 5; table A5). This clustered occurrence pattern was not as pronounced for nonapex predators that were less negatively impacted by wolves at a landscape scale (red fox, lynx, and marten). Although this study had insufficient replication to attribute these differences to wolf density alone, this pattern could indicate that apex predator density may have particularly strong effects on the distribution and movements of scavengers that are highly susceptible to suppression.

Our analyses and inferences relied on observational data; however, our study design and modeling approach was designed to strengthen inference and minimize confounding factors in several ways. First, we developed competing hypotheses based on literature review and extensive system knowledge (Platt 1964; Rosenbaum 2002; Ford and Goheen 2015). Second, we used replication at a local spatial scale and accounted for variables most likely to influence system responses at a landscape scale. Third, the use of species-specific occupancy models allowed us to account for imperfect detection among species, thus improving our track count indexes (Hayward et al. 2015). Finally, we took advantage of a landscape-scale wolf management action that manipulated wolf density in a geographic area adjacent to where wolves occur at naturally regulated densities and quantified the effects of prey and habitat conditions most likely to influence the observed patterns. Use of this management manipulation thus allowed for stronger inferences compared to a purely observational study (Rosenbaum 2002).

\section{Conclusion}

Apex predators influence meso- and small predators through direct and indirect mechanisms, yet the complexities driving intraguild interactions that lead to mesopredator release make predicting the outcomes of these ecological cascades extremely challenging. We quantified the relative strengths of wolves, prey, and snowpack on patterns of meso- and small predator occurrence, presenting the first community-level investigation of the direct and indirect influences of an apex predator on an intact predator guild. The cascading effects of mesopredator release could depend on mesopredator densities, as we detected minimal influence of coyotes on other mesopredators when productivity (e.g., small prey) was low. Wolves were strong predictors of mesopredator occurrence, which suggested that mesopredators could be tracking wolves for scavenging, especially where wolves are more abundant. The local-scale patterns we observed suggest an intriguing mechanism to account for the contrasting effects of apex predators with respect to spatial scale. Studies examining mesopredator release have documented cascades at continental scales in North America, Europe, and Australia (Johnson et al 2007; Letnic et al. 2011; Levi and Wilmers 2012; PasanenMortensen et al. 2013; Khalil et al. 2014; Lapoint et al. 2014; Krofel et al. 2017). However, studies conducted at finer spatial scales have had mixed findings (Mitchell and Banks 2005; Gehrt and Prange 2007; Berger et al. 2008; Allen et al. 2014, 2015; Colman et al. 2014). The contrasting patterns detected within versus between study areas elicits the question of whether local-scale facilitation by wolves, indicated by positive associations of mesopredators with wolves within study sites, could lead to landscape patterns of suppression. Our results indicate that facilitation could be an important consideration for interpreting and predicting predator community structure and evaluating evidence of predator cascades. Facilitation by scavenging is common to more than just mammalian carnivore communities and applies to any predator guild. Our findings suggest a potential mechanistic link between abundance patterns and the structure of predator communities at different spatial scales and could have important implications for general theory of predator community structure, which has largely focused on negative interaction pathways to explain predator co-occurrence and abundance patterns. Examination of scavenging benefits contrasted with scavenging-related mortality risk could greatly aid our understanding of the influence of apex predators on mesopredators at spatial scales relevant to conservation and management.

\section{Acknowledgments}

We thank all the human and canine field volunteers, community members, University of Alaska Fairbanks staff, Alaska Department of Fish and Game, and National Park Service personnel who contributed time, resources, and effort toward this project. J. Reppert, C. Bondy, and P. Baigas provided invaluable field assistance. Wolf collar data was provided by S. Arthur and B. Borg from Denali National Park and Preserve (DNPP). K. Klauder assisted with camera data. Alpine Creek Lodge, Alaska Earth Sciences, Alaska Biological Research, Murie Science and Learning Center, Alaska Geographic, and DNPP provided administrative and logistics support. S. Arthur, B. Borg, K. Kielland, and M. Lindberg provided discussion throughout the study; we also thank J. Bronstein and M. Leibold for insightful comments that benefitted the final article. J.B.G was supported by the USGS Ecosystems and Climate and Land Use Change Programs. Funding was provided by the Institute of Arctic Biology at the University of Alaska Fairbanks, grants from the Alaska Energy Authority (RSA 1331) and National Science Foundation (NSF; DEB-1652420) to L.R.P., and a Discover Denali Fellowship and NSF Graduate Research Fellowship (2012136814) to K.J.S. Any use of trade, firm, or product names is for descriptive purposes only and does not imply endorsement by the United States government. 


\section{Literature Cited}

Alaska Department of Fish and Game. 2015. Annual report to the Alaska Board of Game on intensive management for moose with wolf predation control in Unit 13. Division of Wildlife Conservation.

Allen, M. L., L. M. Elbroch, C. C. Wilmers, and H. U. Wittmer. 2014. Trophic facilitation or limitation? comparative effects of pumas and black bears on the scavenger community. PLoS ONE 9:e102257. http:// dx.doi.org/10.1371/journal.pone.0102257.

- 2015. The comparative effects of large carnivores on the acquisition of carrion by scavengers. American Naturalist 185:822-833.

Allen, M. L., C. C. Wilmers, L. Mark Elbroch, J. M. Golla, and H. U. Wittmer. 2016. The importance of motivation, weapons and foul odors in driving encounter competition in carnivores. Ecology 97: 1905-1912.

Arjo, W. M., and D. H. Pletscher. 1999. Behavioral responses of coyotes to wolf recolonization in northwestern Montana. Canadian Journal of Zoology 77:1919-1927.

Atwood, T. C., and E. M. Gese. 2008. Coyotes and recolonizing wolves: social rank mediates risk-conditional behaviour at ungulate carcasses. Animal Behaviour 75:753-762.

2010. Importance of resource selection and social behavior to partitioning of hostile space by sympatric canids. Journal of Mammology 91:490-499.

Atwood, T. C., E. M. Gese, and K. E. Kunkel. 2009. Spatial partitioning of predation risk in a multiple predator-multiple prey system. Journal of Wildlife Management 73:876-884.

Bailey, L. L., D. I. MacKenzie, and J. D. Nichols. 2014. Advances and applications of occupancy models. Methods in Ecology and Evolution 5:1269-1279.

Banci, V., and A. Harestad. 1990. Home range and habitat use of wolverines Gulo gulo in Yukon, Canada. Ecography 13:195-200.

Bates, D., M. Mächler, B. Bolker, and S. Walker. 2015. Fitting linear mixed-effects models using lme4. Journal of Statistical Software 67: $1-48$.

Berger, K. M., and E. M. Gese. 2007. Does interference competition with wolves limit the distribution and abundance of coyotes? [ournal of Animal Ecology 76:1075-1085.

Berger, K. M., E. M. Gese, and J. Berger. 2008. Indirect effects and traditional trophic cascades: a test involving wolves, coyotes, and pronghorn. Ecology 89:818-828.

Boggs, K. A., A. Garibaldi, J. L. Stevens, J. Grunblatt, and T. Helt. 2001. Denali National Park and Preserve landcover mapping project, vol. 2: landcover classes and plant associations. Natural Resource Technical Report NPS/DENA/NRTR-2001/002. National Park Service, Fort Collins, CO.

Bolker, B. M., M. E. Brooks, C. J. Clark, S. W. Geange, J. R. Poulsen, M. H. Stevens, and J. S. White. 2008. Generalized linear mixed models: a practical guide for ecology and evolution. Trends in Ecology and Evolution 24:127-135.

Borg, B. L., S. M. Brainerd, T. J. Meier, and L. R. Prugh. 2014. Impacts of breeder loss on social structure, reproduction and population growth in a social canid. Journal of Animal Ecology 84:177-187.

Boutin, S., C. J. Krebs, R. Boonstra, M. R. T. Dale, S. J. Hannon, K. Martin, and R. E. Sinclair. 1995. Population changes of the vertebrate community during a snowshoe hare cycle in Canada's boreal forest. Oikos 74:69-80.

Brand, C. J., L. B. Keith, and C. A. Fischer. 1976. Lynx response to changing snowshoe hare densities in central Alberta. Journal of Wildlife Management 40:416-428.
Broekhuis, F., G. Cozzi, M. Valeix, J. W. Mcnutt, and D. W. Macdonald. 2013. Risk avoidance in sympatric large carnivores: reactive or predictive? Journal of Animal Ecology 82:1098-1105.

Bruno, J. F., J. J. Stachowicz, and M. D. Bertness. 2003. Inclusion of facilitation into ecological theory. Trends in Ecology and Evolution 18:119-125.

Burnham, K. P., and D. R. Anderson. 2002. Model selection and multimodel inference: a practical information-theoretic approach. Springer, New York.

Burton, C. A., M. K. Sam, C. Balangtaa, and J. S. Brashares. 2012. Hierarchical multi-species modeling of carnivore responses to hunting, habitat and prey in a West African protected area. PLoS ONE 7: e38007. http://dx.doi.org/10.1371/journal.pone.0038007.

Buskirk, S. W. 1983. The ecology of marten in Southcentral Alaska. PhD diss. University of Alaska, Fairbanks.

Caro, T. M., and C. J. Stoner. 2003. The potential for interspecific competition among African carnivores. Biological Conservation 110:6775.

Chapron, G., P. Kaczensky, J. Linnel, M. von Arx, D. Huber, H. Andrén, J. V. López-Bao, et al. 2014. Recovery of large carnivores in Europe's modern human-dominated landscapes. Science 346:1517-1520.

Colman, N. J., C. E. Gordon, M. S. Crowther, and M. Letnic. 2014. Lethal control of an apex predator has unintended cascading effects on forest mammal assemblages. Proceedings of the Roval Society B 281:20133094. http://dx.doi.org/10.1098/rspb.2013.3094.

Cortés-Avizanda, A., N. Selva, M. Carrete, and J. A. Donázar. 2009. Effects of carrion resources on herbivore spatial distribution are mediated by facultative scavengers. Basic and Applied Ecology 10:265272.

Creel, S. 2001. Four factors modifying the effect of competition on carnivore population dynamics as illustrated by African wild dogs. Conservation Biology 15:271-274.

Creel, S., and N. M. Creel. 1996. Limitation of African wild dogs by competition with larger carnivores. Conservation Biology 10:526-538.

Dalerum, F., K. Kunkel, A. Angerbjörn, and B. S. Shults. 2009. Diet of wolverines (Gulo gulo) in the western Brooks Range, Alaska. Polar Research 28:246-253.

Donadio, E., and S. W. Buskirk. 2006. Diet, morphology, and interspecific killing in carnivora. American Naturalist 167:524-536.

Durant, S. M. 1998. Competition refuges and coexistence: an example from Serengeti carnivores. Journal of Animal Ecology 67:370-386.

Elmhagen, B., G. Ludwig, S. P. Rushton, P. Helle, and H. Linden. 2010. Top predators, mesopredators and their prey: interference ecosystems along bioclimatic productivity gradients. Lournal of Animal Ecology 79:785-794.

Elmhagen, B., and S. P. Rushton. 2007. Trophic control of mesopredators in terrestrial ecosystems: top-down or bottom-up? Ecology Letters 10:197-206.

Ford, A. T., and J. R. Goheen. 2015. Trophic cascades by large carnivores: a case for strong inference and mechanism. Trends in Ecology and Evolution 30:725-735.

Fuller, T., and L. Keith. 1981. Non-overlapping ranges of coyotes and wolves in northeastern Alberta. Lournal of Mammalogy 62:403405.

Gehrt, S. D., and S. Prange. 2007. Interference competition between coyotes and raccoons: a test of the mesopredator release hypothesis. Behavioral Ecology 18:204-214.

Gese, E. M., R. L. Ruff, and R. L. Crabtree. 1996. Social and nutritional factors influencing the dispersal of resident coyotes. Animal Behaviour 52:1025-1043. 
Grace, J. 2006. Structural equation modeling and natural systems. Cambridge University Press, Cambridge.

Grace, J., and K. Bollen. 2005. Interpreting the results from multiple regression and structural equation models. Bulletin of the Ecological Societv of America 86:283-295.

Grace, J., S. Scheiner, and D. Schoolmaster. 2015. Structural equation modeling: building and evaluating causal models. Pages 168-199 in G. Fox, S. Negret-Yankelevich, and V. Sosa, eds. Ecological statistics: contemporary theory and application. Oxford University Press, Oxford.

Greenville, A. C., G. M. Wardle, B. Tamayo, and C. R. Dickman. 2014. Bottom-up and top-down processes interact to modify intraguild interactions in resource-pulse environments. Oecologia 175:1349-1358.

Hayward, M. W., L. Boitani, N. D. Burrows, P. J. Funston, K. U. Karanth, D. I. MacKenzie, K. H. Pollock, and R. W. Yarnell. 2015. FORUM: ecologists need robust survey designs, sampling and analytical methods. Journal of Applied Ecology 52:286-290.

Hilborn, R., and M. Mangel. 1997. The ecological detective: confronting models with data. Vol. 28. Princeton University Press, Princeton, NJ.

Hines, J. 2009. Program PRESENCE v2.4. US Geological Survey, Patuxent Wildlife Research. https://www.mbr-pwrc.usgs.gov/software /presence.html.

Holt, R. D., and G. A. Polis. 1997. A theoretical framework for intraguild predation. American Naturalist 149:745-764.

Johnson, C. N., J. L. Isaac, and D. O. Fisher. 2007. Rarity of a top predator triggers continent-wide collapse of mammal prey: dingoes and marsupials in Australia. Proceedings of the Roval Society B 274:341346

Joseph, M. B., D. L. Preston, and P. T. J. Johnson. 2016. Integrating occupancy models and structural equation models to understand species. Ecology 97:765-775.

Kendall, W. L., J. E. Hines, J. D. Nichols, and E. H. C. Grant. 2013. Relaxing the closure assumption in occupancy models: staggered arrival and departure times. Ecology 94:610-617.

Khalil, H., M. Pasanen-Mortensen, and B. Elmhagen. 2014. The relationship between wolverine and larger predators, lynx and wolf, in a historical ecosystem context. Oecologia 175:625-637.

Knopff, K. H., A. A. Knopff, M. B. Warren, and M. S. Boyce. 2009. Evaluating global positioning system telemetry techniques for estimating cougar predation parameters. Journal of Wildlife Management 73 586-597.

Kolbe, J. A., J. R. Squires, D. H. Pletscher, and L. F. Ruggiero. 2007. The effect of snowmobile trails on coyote movements within lynx home ranges. Journal of Wildlife Management 71:1409-1418.

Korpimaki, E., and C. J. Krebs. 1996. Predation and population cycles of small mammals. Bioscience 46:754-764.

Krebs, C. J., S. A. Boutin, and R. Boonstra. 2001. Ecosystem dynamics of the boreal forest: the Kluane project. Vol. 1. Oxford University Press, New York City.

Krebs, C. J., K. Kielland, J. Bryant, M. O'Donoghue, F. Doyle, C. McIntyre, D. DiFolco, et al. 2013. Synchrony in the snowshoe hare (Lepus americanus) cycle in northwestern North America, 1970-2012. Canadian Journal of Zoology 91:1-11.

Krebs, C. J., E. Lofroth, J. Copeland, V. Banci, D. Cooley, H. Golden, A. Magoun, R. Mulders, and B. Shults. 2004. Synthesis of survival rates and causes of mortality in North American wolverines. Iournal of Wildlife Management 68:493-502.

Kreig, R. A. 1987. Susitna hydroelectric project, vegetation mapping final report and user guide. Alaska Power Authority Doc. No. 1321.
Kreig and Associates for Harza-Ebasco Susitna Joint Venture, Anchorage, AL.

Krofel, M., G. Giannatos, D. Cirovic, S. Stoyanov, and T. M. Newsome. 2017. Golden jackal expansion in Europe: a case of mesopredator release triggered by continent-wide wolf persecution? Hystrix, http:// dx.doi.org/10.4404/hystrix-28.1-11819.

Lake, B. C., M. R. Bertram, N. Guldager, J. R. Caikoski, and R. O. Stephenson. 2013. Wolf kill rates across winter in a low-density moose system in Alaska. Lournal of Wildlife Management 77:1512-1522.

Lapoint, S. D., J. L. Belant, and R. W. Kays. 2014. Mesopredator release facilitates range expansion in fisher. Animal Conservation 18:5061.

Letnic, M., A. Greenville, E. Denny, C. R. Dickman, M. Tischler, C. Gordon, and F. Koch. 2011. Does a top predator suppress the abundance of an invasive mesopredator at a continental scale? Global Ecology and Biogeography 20:343-353.

Letnic, M., E. G. Ritchie, and C. R. Dickman. 2012. Top predators as biodiversity regulators: the dingo Canis lupus dingo as a case study. Biological Reviews of the Cambridge Philosophical Society 87:390-413.

Levi, T., and C. C. Wilmers. 2012. Wolves-coyotes-foxes: a cascade among carnivores. Ecology 93:921-929.

Linnell, J. D. C., and O. Strand. 2000. Interference interactions, coexistence and conservation of mammalian carnivores. Diversitv and Distributions 6:169-176.

MacKenzie, D., J. Nichols, and J. Royle. 2005. Occupancy estimation and modeling: inferring patterns and dynamics of species occurrence. Elsevier, San Diego, CA.

MacKenzie, D. I., and L. L. Bailey. 2004. Assessing the fit of site-occupancy models. Iournal of Agricultural, Biological, and Environmental Statistics 9:300-318.

Mattisson, J., H. Andrén, J. Persson, and P. Segerström. 2011. Influence of intraguild interactions on resource use by wolverines and Eurasian lynx. Journal of Mammalogy 92:1321-1330.

Mech, L., L. Adams, T. Meier, J. Burch, and B. Dale. 1998. The wolves of Denali. University of Minnesota Press, Minneapolis.

Meier, T. J., J. W. Burch, D. Wilder, and M. Cook. 2009. Wolf monitoring protocol for Denali National Park and Preserve, Yukon-Charley Rivers National Preserve and Wrangell-St. Elias National Park and Preserve, Alaska. Natural Resource Report NPS/CAMN/NRR-2009 /168, Fort Collins, CO.

Merkle, J. A., D. R. Stahler, and D. W. Smith. 2009. Interference competition between gray wolves and coyotes in Yellowstone National Park. Canadian Journal of Zoology 87:56-63.

Mitchell, B. D., and P. B. Banks. 2005. Do wild dogs exclude foxes? evidence for competition from dietary and spatial overlaps. Austral Ecology 30:581-591.

Needham, R., and M. Odden. 2014. Seasonal diets of red foxes in a boreal forest with a dense population of moose: the importance of winter scavenging. Acta Theriologica 59:391-398.

Newsome, T. M., and W. J. Ripple. 2015. A continental scale trophic cascade from wolves through coyotes to foxes. Iournal of Animal Ecology 84:49-59.

O’Donoghue, M., S. Boutin, C. J. Krebs, and E. J. Hofer. 1997a. Behavioural responses of coyotes and lynx to the snowshoe hare cycle. Oikos 80:169-183.

1997b. Numerical responses of coyotes and lynx to the snowshoe hare cycle. Oikos 80:150-162.

Oksanen, L., S. D. Fretwell, J. Arruda, and P. Niemela. 1981. Exploitation ecosystems in gradients of primary productivity. American Naturalist 118:240-261. 
Ostfeld, R. S., and F. Keesing. 2000. Pulsed resources and community dynamics of consumers in terrestrial ecosystems. Trends in Ecology and Evolution 15:232-237.

Palomares, F., and T. M. Caro. 1999. Interspecific killing among mammalian carnivores. American Naturalist 153:492-508.

Palomares, F., P. Ferreras, J. M. Fedriani, and M. Delibes. 1996. Spatial relationships between Iberian lynx and other carnivores in an area of South-western Spain. Journal of Applied Ecology 33:5-13.

Paquet, P. C. 1991. Winter spatial relationships of wolves and coyotes in Riding Mountain National Park, Manitoba. Journal of Mammology 72:397-401.

Parker, G. 1995. Eastern coyote: the story of its success. Nimbus, Halifax.

Pasanen-Mortensen, M., M. Pyykönen, and B. Elmhagen. 2013. Where lynx prevail, foxes will fail- limitation of a mesopredator in Eurasia. Global Ecology and Biogeography 22:868-877.

Pereira, L. M., N. Owen-Smith, and M. Moleón. 2014. Facultative predation and scavenging by mammalian carnivores: seasonal, regional and intra-guild comparisons. Mammal Review 44:44-55.

Pianka, E. R. 1981. Competition and niche theory. Pages 167-196 in R. M. May, ed. Theoretical ecology: principle and applications. W. B. Saunders, Philadelphia.

Poole, K. G. 2003. A review of the Canada lynx, Lynx canadensis, in Canada. Canadian Field-Naturalist 117:360-376.

Pozzanghera, C. B. 2015. Non-invasive methods for obtaining occupancy probabilities and density estimates of interior Alaska's mesocarnivore populations. MS thesis. University of Alaska, Fairbanks.

Pozzanghera, C. B., K. J. Sivy, M. S. Lindberg, and L. R. Prugh. 2016. Variable effects of snow conditions across boreal mesocarnivore species. Canadian Journal of Zoology 94:697-705.

Platt, J. R. 1964. Strong inference. Science 146:347-353.

Prugh, L. R. 2005. Coyote prey selection and community stability during a decline in food supply. Oikos 110:253-264.

Prugh, L. R., and S. M. Arthur. 2015. Optimal predator management for mountain sheep conservation depends on the strength of mesopredator release. Oikos, http://dx.doi.org/10.1111/oik.02017.

Prugh, L. R., C. J. Stoner, C. W. Epps, W. T. Bean, W. J. Ripple, A. S. Laliberte, and J. S. Brashares. 2009. The rise of the mesopredator. BioScience 59:779-791.

Richmond, O. M. W., J. E. Hines, and S. R. Beissenger. 2010. Twospecies occupancy models: a new parameterization applied to cooccurrence of secretive rails. Ecological Applications 20:2036-2046.

Ripple, W. J., J. A. Estes, R. L. Beschta, C. C. Wilmers, E. G. Ritchie, M. Hebblewhite, J. Berger, et al. 2014. Status and ecological effects of the world's largest carnivores. Science 343:1241484.

Ripple, W. J., A. J. Wirsing, R. L. Beschta, and S. W. Buskirk. 2011. Can restoring wolves aid in lynx recovery? Wildlife Societv Bulletin 35:514-518.

Ripple, W. J., A. J. Wirsing, C. C. Wilmers, and M. Letnic. 2013. Widespread mesopredator effects after wolf extirpation. Biological Conservation 160:70-79.

Ritchie, E. G., and C. N. Johnson. 2009. Predator interactions, mesopredator release and biodiversity conservation. Ecology Letters 12: 982-998.

Roemer, G. W., M. E. Gompper, and B. Van Valkenburgh. 2009. The ecological role of the mammalian mesocarnivore. BioScience 59:165-173. Rosenbaum, P. R. 2002. Observational studies. Springer, New York. Sand, H., B. Zimmermann, P. Wabakken, H. Andren, and H. C. Pedersen. 2005. Using GPS technology and GIS cluster analyses to es- timate kill rates in wolf-ungulate ecosystems. Wildlife Societv Bulletin 33:914-925.

Selva, N., and M. A. Fortuna. 2007. The nested structure of a scavenger community. Proceedings of the Roval Society B 274:1101-1108.

Sivy, K. 2015. Direct and indirect effects of wolves on mesopredators in interior Alaska. MS thesis, University of Alaska, Fairbanks.

Sivy, K. J, C. B. Pozzanghera, J. B. Grace, amd L .R. Prugh. 2017. Data from: Fatal attraction? intraguild facilitation and suppression among predators. American Naturalist, Dryad Digital Repository, http://dx .doi.org/10.5061/dryad.tj590.

Smith, D. W., R. O. Peterson, and D. B. Houston. 2003. Yellowstone after wolves. BioScience 53:330-340.

Stachowicz, J. 2001. Mutualism, facilitation, and the structure of ecological communities. BioScience 51:235-246.

Swanson, A., T. Caro, H. Davies Mostert, M. G. L. Mills, D. W. Macdonald, M. Borner, E. Masenga, and C. Packer. 2014. Cheetahs and wild dogs show contrasting patterns of suppression by lions. Journal of Animal Ecology 83:1418-1427.

Thurber, J. M., R. O. Peterson, J. D. Woolington, and J. A. Vucetich. 1992. Coyote coexistence with wolves on the Kenai Peninsula, Alaska. Canadian Journal of Zoology 70:2494-2498.

Van Dijk, J., T. Andersen, R. May, R. Andersen, R. Andersen, and A. Landa. 2008a. Foraging strategies of wolverines within a predator guild. Canadian Journal of Zoology 86:966-975.

Van Dijk, J., L. Gustavsen, A. Mysterud, R. May, Ø. Flagstad, H. Brøseth, R. Andersen, R. Andersen, H. Steen, and A. Landa. 2008b. Diet shift of a facultative scavenger, the wolverine, following recolonization of wolves. Journal of Animal Ecology 77:1183-1190.

Vanak, A. T., D. Fortin, M. Thaker, M. Ogden, C. Owen, S. Greatwood, and R. Slotow. 2013. Moving to stay in place: behavioral mechanisms for coexistence of African large carnivores. Ecology 94:2619-2631.

Weiher, E., and P. Keddy. 1999. Ecology assembly rules: perspectives, advances, retreats. Cambridge University Press, Cambridge.

West, S. G., A. B. Taylor, and W. Wu. 2012. Model fit and model selection in structural equation modeling. Pages 209-231 in R. H. Hoyle, ed. Handbook of structural equation modeling. Guilford, New York.

Wilmers, C. C., R. L. Crabtree, D. W. Smith, K. M. Murphy, and W. M. Getz. 2003a. Trophic facilitation by introduced top predators: grey wolf subsidies to scavengers in Yellowstone National Park. Journal of Animal Ecology 72:909-916.

Wilmers, C. C., D. R. Stahler, R. L. Crabtree, D. W. Smith, and W. M. Getz. 2003b. Resource dispersion and consumer dominance: scavenging at wolf- and hunter-killed carcasses in Greater Yellowstone, USA. Ecology Letters 6:996-1003.

Wilson, E. E., and E. M. Wolkovich. 2011. Scavenging: how carnivores and carrion structure communities. Trends in Ecology and Evolution 26:129-135.

Yarnell, R. W., W. L. Phipps, L. P. Burgess, J. A. Ellis, S. W. R. Harrison, S. Dell, D. MacTavish, L. M. MacTavish, and D. M. Scott. 2013. The influence of large predators on the feeding ecology of two African mesocarnivores: the black-backed jackal and the brown hyaena. South African Journal of Wildlife Research 43:155-166.

Zar, J. H. 1999. Biostatistical analysis. Prentice Hall, Upper Saddle River, NJ. 